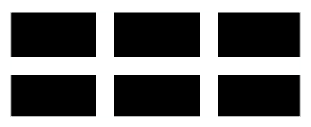

ThE WILLIAM DAVIDSON INSTITUTE

AT THE UNIVERSITY OF MICHIGAN BUSINESS SCHOOL

\title{
Network Triads: Transitivity, Referral and Venture Capital Decisions in China and Russia
}

\author{
By: Bat Batjargal \\ William Davidson Institute Working Paper Number 752 \\ February 2005
}


NETWORK TRIADS: TRANSITIVITY, REFERRAL AND VENTURE CAPITAL DECISIONS IN CHINA AND RUSSIA

\author{
BAT BATJARGAL \\ Harvard University \\ Davis Center for Russian and Eurasian Studies \\ 625 Massachusetts Avenue \\ Cambridge, MA 02139 \\ Email: batjarg@fas.harvard.edu \\ Peking University \\ Guanghua School of Management \\ Beijing, 100781 \\ China \\ Email: batjargal@gsm.pku.edu.cn
}

${ }^{*}$ I thank Frances Fu, Alena Novikova, Dima Romanov, Oksana Sergeeva, Steve Sun, Tony Tang,
Vincent Xin, William Wu and Jane Yu for excellent research assistance. I wish to thank Tim
Colton, Marshall Goldman, Andrei Kolesnikov, Lyudmila Kolesnikova, Liz Tarlow, Weiying
Zhang, Shanli Zhu, and Dean Xu for their support. The financial support from the Guanghua
School of Management of Peking University is acknowledged gracefully. 


\title{
NETWORK TRIADS: TRANSITIVITY, REFERRAL AND VENTURE CAPITAL DECISIONS IN CHINA AND RUSSIA
}

\begin{abstract}
This article examines effects of dyadic ties and interpersonal trust on referrals and investment decisions of venture capitalists in the Chinese and Russian contexts. The study uses the postulate of transitivity of social network theory as a conceptual framework. The findings reveal that referee-venture capitalist tie, referee-entrepreneur tie, and interpersonal trust between referee and venture capitalist have positive effects on referrals and investment decisions of venture capitalists. The institutional, social and cultural differences between China and Russia have minimal effects on referrals. Interpersonal trust has positive effects on investment decisions in Russia.
\end{abstract}

Key words: Transitivity, triads, referral, venture capital, China, Russia. JEL Codes: G24; D85; M13; P27 
Social network theory postulates that personal networks of actors tend to be transitive: one's friends' friends are likely to become one's friends as well (Granovetter 1973). Transitivity is a tendency that two actors who are connected to a third-party form mutual relationships over time. The main reason why triads, i.e., triples of actors, tend to be transitive is that actors strive to reduce inconsistencies and uncertainties in their social and cognitive worlds, and attempt to establish balances in interpersonal relationships (Heider 1964; Holland and Leinhardt 1976). For example, in friendship triads, unbalanced relationships, i.e., $E$ likes $R$ and $R$ likes $V$, but $E$ does not like $V$ (See Figure 1), may cause emotional tensions, and therefore, actors try to make triads complete by forming friendly relations with other actors or withdrawing from that triad (Krackhardt and Kilduff 1999). Empirical studies have consistently found that the principle of transitivity applies in about 70-80 percent of all cases across a variety of small group situations (Davis 1970; Robinson and Balkwell 1995).

Insert Figure 1 about here

Whether a triad is transitive or intransitive, however, depends on various factors. Granovetter (1973) argued that transitivity is a function of the strength of dyadic ties in triads. He suggested that let $E$ choose $R$, and $R$ choose $V$ (or equivalently, let $V$ choose $R$, and $R$ choose $E$ ), then transitivity $-E$ choosing $V$ (or $V, E$ ) - is most likely when both ties $-E-R$ and $R-V$-are strong, least likely when both are weak, and intermediate probability if one is strong and one is weak. Hallinan and Hutchins (1980) found that triads composed of boys were more transitive than triads composed of girls. Similarly, Louch (2000) reported that triads comprised of homogeneous actors in terms of race, education, and religion, were more transitive and integrated over time than heterogeneous triads. Burt (1999) concluded that triads were more likely to be cohesive and balanced when there is trust between three actors. In the context of research collaboration among scientists, Newman (2001) documented that those scientists who have had common co-authors were more likely to collaborate and form relationships over time than those who did not share authorship. At the inter-organizational level, Uzzi and Gillespie (2002) found that small firms learn from embedded relationships with their banks, and leverage that financial knowledge in relationships with their trade-creditors. They argued that knowledge transfers in triads improve firms' debt performance. The empirical evidence on transitivity suggests that two actors who are connected to a third party are likely to form a certain type of relationship, depending on the strength of ties, interpersonal trust, demographic characteristics, 
and homophily, because of the propensity of actors to balance their social relationships (Holland and Leinhardt 1976). Ties initiated, formed, and maintained between two actors in triads may have various contents such as friendship, information sharing, scientific collaboration, and learning.

In this study, I focus on venture capital (VC) referral and investment decision as indicators of transitivity in triads. Venture capital referral is defined as a third-party's recommendation of an entrepreneur as a potential equity capital receiver to a venture capitalist. Investment decision is defined as a venture capitalist's decision to invest or not-to-invest in a venture. Previous studies of venture capital examined investment oversight (Lerner 1995), the role of private equity in product development (Hellman and Puri 2000), spatial distribution of investments (Sorenson and Stuart 2001), entrepreneur-venture capitalist interactions in the postinvestment period (Cable and Shane 1997; Sapienza and Korsgaard 1996), and effects of direct and indirect ties of entrepreneurs and venture capitalists on investment decisions (Shane and Cable 2002; Shane and Stuart 2002).

Using the concept of transitivity, I examine the impact of dyadic ties between three actors, namely, entrepreneur - $E$, venture capitalist - $V$, and third-party referee - $R$, on venture capital referral, and investment decision in the Chinese and Russian contexts. I propose that strong ties between referee, venture capitalist, and entrepreneur affect positively third-party referral and investment decision, because of the transitive nature of triads. I suggest that the way in which dyadic relationships in triads affects referral and investment decision differs in China and Russia, because of the institutional, social, and cultural differences between the two countries (Hitt et al. 2004).

This article is structured as follows: In the next section, I describe the Chinese and the Russian contexts. In the following section, I propose hypotheses on referral and investment decision. The methods section describes the sample, the data collection, the measurements, and the construct validation procedures. In the results and discussion sections, I present the findings and discuss them in light of social network theory. In the conclusion, I highlight the contributions, the limitations, and the implications of this study. 


\section{CONTEXTS}

\section{The Chinese Context}

The Chinese Private Equity Industry. The Chinese VC industry is the largest private equity industry in Asia. In 2001, China, together with Hong Kong, captured 30\% of Asia's private equity investment. By the middle of 2002, the total VC fund pool in mainland China reached US\$7.15 billion (Business Weekly 2003). In 2003, China attracted $\$ 1.57$ billion in foreign private equity (BusinessWeek, 2004). There were 325 domestic VC firms registered in China by mid2002 (Business Weekly 2003). Some 60 foreign VC firms operate in China (Liu 2001). In the first two quarters of 2002, \$175 million were invested in 85 projects. Some 36 foreign firms invested \$87 million while Chinese firms invested \$70 million (Business Weekly 2003).

Although the Chinese VC industry has taken off rather well, some serious institutional, regulatory, and human capital issues remain unresolved. The main legal form of VC firms — limited liability partnership — is not recognized in China's laws. Therefore, all VC firms are registered and operate as limited liability companies, adding confusion as well as serious risks to the processes by which VC firms raise, invest, and manage funds. Rights and responsibilities of general partners (fund managers) versus limited partners (investors in funds) are not adequately defined under the law. Furthermore, the assets of the VC firm are not separated legally from those of the fund, thus increasing agency risks in venture investments, such as misuse of funds. The state's participation is immense, and it often plays roles of shareholder, investor, fund manager, and auditor of VC firms simultaneously. This situation exacerbates the regulatory chaos and uncertain external environment for VC firms.

Social Networks in China: Guanxi. The Chinese version of social networks is guanxi (Xin and Pearce 1996). Guanxi is defined as special relationships due to the existence of particularistic ties (Tsui et al. 2000). Guanxi ties promote interpersonal trust (Farh et al. 1998), facilitate job mobility (Bian 1997), and enhance firm performance (Park and Luo 2001). In the context of private equity, researchers found that Chinese venture capitalists rely heavily on guanxi ties to reduce uncertainties and use universalistic investment criteria in particularistic ways to make investment decisions (Batjargal and Liu 2004; Bruton and Ahlstrom 2003).

\section{The Russian Context}

The Russian Private Equity Industry. The Russian VC industry is slightly older and much smaller than the Chinese industry. There were more than 40 domestic VC firms with total funds 
of $\$ 4$ billion (E-Trust Investment Group 2004). These funds invested $\$ 600$ million in more than 300 projects during 1994-2001. The weighted average return on investment is $16 \%$. Some $27 \%$ of investment funds went into food industry, 9\%-medical services and pharmaceuticals, 5\%-packaging, and 25\% were invested into technology startups. International development agencies such as IMF and European Bank of Reconstruction and Development (EBRD) set up 10 regional venture funds with total capital of $\$ 320$ million in the early 1990s (Tacis 2001). These firms were first dedicated VC companies in the country. Increasingly, large Russian corporations such as LUKoil and Alpha Capital are setting up VC funds that invest in technology startups. In this respect, Russia differs from China where foreign donor agencies do not run VC funds and private corporations play limited roles.

Despite its impressive growth, the Russian VC firms face serious economic, regulatory and institutional uncertainties. The Russian government has no supportive policy of private equity investment. The legal framework is as primitive as it is in China. For example, the use of preferred stock and other convertible securities is not permitted. Like in China, limited exit routes prevent flows of capital into equity funds. Most domestic VC firms are concentrated in Moscow, in contrast to China where VC funds are located in 53 high tech zones across the country.

Social Networks in Russia: Svyazi. The Russian version of social networks is svyazi (connections). Some scholars referred to Russian networks as blat - a set of informal ties central to economic survival in the Soviet economy of shortages (Ledeneva 1998). Previous research found that svyazi networks reduce uncertainties in financial transactions (Guseva and Rona-Tas 2001), and facilitate entrepreneurs' access to resources (Sedaitis 1998).

\section{HYPOTHESES}

\section{Referral and Investment Decision}

It is common practice in private equity industry that entrepreneurs and venture capitalists get connected through third-parties who recommend founders and investors to each other (Shane \& Stuart 2002). For example, roughly $50 \%$ of private equity deals in China were based on thirdparty recommendations (Sheng et al. 2003). I propose that strong ties between entrepreneurs, venture capitalists, and referees influence third-party recommendations or referrals.

When the referee-venture capitalist tie is strong, referees are motivated to find and recommend promising projects, and therefore, they screen large pools of actors who are not 
connected directly to the investor (Fernandez et al. 2000). These referees are likely to regard highly those teams whom they chosen to recommend, and this positive assessment leads to strong referrals. Friendly relations between referees and venture capitalists enable referees to know well investment preference, post-investment involvement, and personality of venture capitalists. This knowledge helps referees to select those teams that match investors' requirements, and this matching motivates referees to issue strong recommendations (Fernandez et al. 2000). An important factor that influences referrals is third-parties' awareness that by filtering and finding promising startups, they reduce search and identification costs of investors, and in this way, they do favors for their friends (Burt 1992; Fernandez \& Castilla 2001). Therefore, referees would recommend strongly selected venture teams to investors, who are their friends. By connecting good startup teams with investors, referees manufacture social debts of venture capitalists to them, and therefore, they may be inclined to generate more convincing recommendations, because it increases their social "receivables” (Yang 1994). Friendships may create a sense of certainty, and increase referees' confidence in positive outcomes of transactions, and therefore, third-parties may send strong referrals (Batjargal \& Liu 2004). Interpersonal liking between friends may also influence referrals, because intermediaries are likely to see recommendations as a social act that make triads complete and balanced (Holland \& Leinhardt 1976). Field interviews revealed consistent findings. A fund manager in a private equity firm said in an interview:

Liu was my dorm-mate at Nangkai University about 20 years ago. But we did not keep in touch for some reasons. Then, we met 2 years ago again at a conference on leveraged buy-out. Although my firm does not invest in new and small firms such as his, we started to talk about possible business opportunities. My partners and I have got to know well of what these guys are up to. Although we were not sure of their business model, we liked their product: a special device that serve as router between mobile and non-mobile communications equipment. Eventually, I linked this team to a university-funded venture capital firm that focuses on telecom and IT ventures (Author’s interview, March 2003, Beijing).

Hypothesis 1: The stronger the tie between the referee and the venture capitalist, the stronger the referral. 
Referee-entrepreneur relationship affects referrals through several mechanisms such as social obligation, informal pressure, information transfer, manufacturing social debts, matching, and propensity of players to balance triads. Third-parties may recommend entrepreneurs strongly because they see this as a fulfillment of their social obligations and meeting their friends' expectations (Shane \& Cable 2002). Entrepreneurs may put informal pressures on referees to be positive about their ventures, and this pressure may strengthen referrals. Lasting relationships and frequent communications between referees and entrepreneurs lead to fine-grained, honest, and timely information exchanges, and this enables referees to obtain objective knowledge about intentions, motives, personality, and post-investment behavior of entrepreneurs. In this way, strong ties reduce referees' social uncertainties and risks. Lowered social risks may be conducive to more persuasive referrals. By recommending entrepreneurs to potential investors, referees generate social “receivables” from entrepreneurs, and strong recommendations produce greater debts of entrepreneurs to third parties (Yang 1994). Because intermediaries are knowledgeable about entrepreneurs' financial plans and strategy, they are likely to select those teams that correspond investors' policy, and this may lead to enthusiastic recommendations. Lastly, because third-parties and entrepreneurs are friends, referees may try to establish good relationships between their friends in order to make their social worlds consistent. In its turn, this generates credible referrals. Evidence from field interviews is consistent with this logic. An investment banker who recommended an entrepreneur to a venture capitalist said in an interview:

Wang and I worked together for 10 years in this bank. I used to work in the product development area, and he was in charge of large customers -heavily indebted state enterprises. It is a tough business. We had our ups and downs but we kept our friendship in tact for years by now. I regard him as a highly motivated, able, and reliable professional, and that is why I introduced him to this venture capitalist. Furthermore, I told the venture capitalist that if they consider seriously his venture, we are willing to provide long-term loans to this company (Author's interview, March 2003, Beijing).

Hypothesis 2: The stronger the tie between the referee and the entrepreneur, the stronger the referral. 
Interpersonal and cognitive trust between referees and venture capitalists may lead to positive investment decisions. Venture capitalists are likely to trust judgments of referees about entrepreneurial team ability, technology/product, and growth potential of the venture (Shane \& Cable 2002). Based on referees' assessment, investors may regard venture teams as able, experienced, and complementarily skilled. In addition, fund managers are likely to perceive entrepreneurs as trustworthy, less opportunistic, and motivated, when they believe in thirdparties. Potential investors may be inclined to assess positively technical and market characteristics of the product, and product development capabilities of the firm, if referees and general partners have enduring trusted relationships. High-trust relationships may lead to optimistic assessments of growth potential of ventures because exchange partners are likely to overestimate each others' capabilities and resources. Strong ties may increase investors' confidence in projected success of ventures, and confident venture capitalists are likely to interpret information about young firms in favorable ways (Zacharakis \& Shepherd 2001). All these factors may influence positively venture capitalists' investment decisions. Ethnographic evidence is consistent with this line of reasoning. A lead fund manager of a private equity firm said in an interview:

There is no doubt that our relationship played an important role in making this decision. Our firm is owned fully by the Chinese Academy of Sciences (CAS), and therefore, we are instructed to invest in spin-offs of the CAS. However, we liked this company because it already had products - wind-resistant paints that were produced by nanotechnology methods. Zhang is a trained chemist, and therefore, we had to rely on his judgment on scientific and technological aspect of this product (Author's interview, September 2003, Beijing).

Hypothesis 3: Trust of referee is associated positively with investment decision.

\section{China versus Russia}

The institutional evolution in China and Russia differs sharply. The Russian reforms resulted in the destruction of existing institutions and networks (Hitt et al, 2004). This forced actors, including entrepreneurs, to restructure their networks and join new clusters (Kharkhordin and Gerber 1994; Sedaitis 1998). In contrast, the institutional status quo in China enabled actors, including entrepreneurs, to preserve their guanxi networks intact over time (Dai 2002; Yang 
1994). Newer network clusters and triads are likely to be intransitive compared to the older and more established triads.

Arguably, Russian society is more mobile both horizontally and vertically, because of the more liberalized labor market and elimination of the household registration system - propiska, and this facilitates people's movement. The Chinese labor market is becoming flexible, although rigidities remain because of the household registration system - hukou that constrains flows of people, ideas, and resources (Bian 1997). This is reflected in greater membership turnover in the Russian networks than in the Chinese networks. This may result in weaker ties and less trust in Russian dyadic and triadic relationships. Furthermore, China and Russia are different in terms of their national culture. The Russian culture is European or Western, and more individualisticoriented, whereas the Chinese culture is Eastern, and more relationship-oriented (Ralston et al, 1997). This implies that the Chinese triads may be more cohesive and transitive, while the Russian triads are less integrated.

The Chinese are more particularistic than the Russians due to the relational Chinese culture (Bian 1997; Tsui et al, 2000). Therefore, guanxi relationships would have greater positive impacts on referrals and investment decisions. In the Russian context, particularistic ties are expected to affect referrals and decisions positively because of the institutional and cultural factors that force actors to rely heavily on personal relationships. However, this impact is likely to be weaker than in China. Dyadic ties are stronger in China, because most network members are recruited according to guanxi base, i.e., propensity to form relationships based on common background, for example, ancestral origin, and classmate (Bian 1997; Farh et al, 1998). In Russia, relational base as a networking principle is not as prevalent as it is in China, and therefore, contact recruitment is less path-dependent and more spontaneous. Strong ties are more motivated to provide relevant information, and deliver useful resources. Actors, who perceive dyadic ties as strong, may be more confident in successful outcomes of transactions, and be biased in each other's capabilities. Therefore, it is expected that the Chinese guanxi will have greater effects on outcome variables.

Social reciprocity is less universal and often ignored in relationships in Russia. This is in sharp contrast to the Chinese guanxi, which contains renching - well-articulated set of expectations and exchange norms (Yang 1994). This may positively influence impacts of dyadic ties and relational trust on referrals and investment decisions. Informal control in triads is 
stronger in China, because there are sophisticated social devices of detecting and sanctioning opportunistic behavior, e.g., saving and losing face (Lin 2001). In contrast, social sanctions used to punish deviant behavior are less severe and effective in Russia, and therefore, network members have greater autonomies in their networking behavior (Ledeneva 1998).

The Chinese networks are denser. They are composed of more family members, schoolmates, and close friends, who have known each other for long time (Yang 1994). The Chinese are strongly inclined to categorize people as belonging to in and out groups, and members of in-groups are expected to fulfill their role obligations and demonstrate group solidarity (Farh et al, 1998). Social relationships are intensely personalized in China, and in this way, the guanxi ties are more multiplex. For example, boundaries between the personal and professional networks in China are blurred. Members of particular guanxi clusters are more homogeneous in terms of knowledge, worldview, and values, because many network members are classmates, who studied the same subjects, and colleagues, who worked together for many years (Farh et al, 1998). Homophily as a selection mechanism favors those who are similar in their worldviews since the social and geographic distances restrict contact search and tie formation (McPherson et al, 2001). The strong in-group pressure and intense guanxi communication homogenizes mindsets of members of a particular guanxi clique over time (Lin 2001). Skillful consensus-making and willingness to accommodate each other's opinions promotes greater perceived intellectual similarity in the Chinese guanxi. Interpersonal trust is higher in China than in Russia, because the institutional stability prevalent in China provides favorable conditions for relatively trustworthy behavior of actors (Raiser et al, 2001). These factors make the Chinese triads more transitive.

In sharp contrast to China, the Russian networks contain greater numbers of structural holes, and are composed of heterogeneous members with regard to their knowledge, worldviews, and values (Sedaitis 1998). The internal hierarchy in the Russian networks is based on power and status, and this generates greater relational distance among network members (Kharkhordin \& Gerber 1994). The Russian triads are less transitive, because there is less trust embedded in triads (Petrovskii 1991). Network brokerage is more accepted, and therefore, the Russian brokers are likely to draw greater values from their intermediate positions (Burt 1992). The Russians have greater opportunities for networking with people of diverse experience and education, because the education system and labor market are more liberalized. There is no dominant networking 
principle, e.g., guanxi base in China, that structures personal networks, and therefore, the Russian networks are composed of alters who differ in their ascribed and achieved attributes (Ledeneva 1994). Because of the less in-group cognitive pressure to internalize and accept views of other alters, the mindsets of Russian members are less homogenized over time. In the contrast to the harmony-loving Chinese, the Russians are more expressive in relationships and do not mind conflicts, and therefore, there is a greater perception of opinion diversity in the Russian networks. These features make the Russian triads less transitive.

Hypothesis 4: The impact of referee-venture capitalist tie on referral will be greater in China than in Russia.

Hypothesis 5: The impact of referee-entrepreneur tie on referral will be greater in China than in Russia.

Hypothesis 6: The impact of trust of referee on investment decision will be greater in China than in Russia.

\section{METHODS}

\section{Sample and Data Collection}

Using several data sources, my research assistants and I created a list of 23 domestic private equity firms based in Moscow. I conducted structured telephone interviews with CEOs and lead fund managers of 15 VC firms in July-August 2004. Six CEOs have declined our request, and two were not reachable. In Beijing, we created a list of 117 domestic VC firms. My assistants and I interviewed 22 CEOs and lead fund managers of VC firms in September-October 2004. Thirty-six CEOs refused to cooperate, and 58 were unreachable. In all, we interviewed 37 CEOs and lead fund managers in two cities.

We asked each fund manager to select the last two positive investment decisions (firm decided to invest) based upon recommendation of third-parties (referees), and the last two negative investment decisions (firm decided not to investment) despite recommendations of third-parties. Thus, we collected information on a maximum of four investment decisions from each respondent. In this way, investments were selected randomly within two groups. In total, we collected information on 122 investment decisions: 61 positive and 61 negative. 
Our sampling of investment decisions is retrospective matched sampling, because positive venture capital decisions are rare events (King and Zeng 2001). This method has been used fruitfully in venture capital research (Sorensen and Stuart 2001) and product innovation research (Eisenhardt and Tabrizi 1995). The use of a matched sample creates two problems. First, it does not accurately account for nonindependence across cases because each firm enters the analysis several times. One way to deal with this problem is to create firm dummies. In this study, however, we are required to create 37 venture capital firm dummies. We did not pursue this procedure for practical reasons. In addition, our sample of venture capital firms is random, and it indirectly mitigates biases of nonindepedence. Second, logistic and linear regression in matched data tends to produce underestimates of the factors that predict a positive outcome (King and Zeng 2001) and biased intercept terms (McCullagh and Nelder 1999). This implies that our findings on regression coefficients are on the conservative side, although we should take biased intercepts into account when we interpret our findings.

The interview questionnaire was designed in English. The English version was translated into Chinese and Russian by teams of two scholars, and the Chinese and the Russian versions were back-translated by two professors of management in each country. In addition, we pretested our questionnaire with two fund managers in Beijing and Moscow. Each interview lasted in 30 minutes.

\section{Measures}

Independents. Referee-venture capitalist tie was measured by two items: "How close are you with the third-party”; “On average, how often do you talk to each third-party” (Cronbach’s alpha is 0.81) (Marsden 1990). These items were 4-point Likert scale items. First item was measured as especially close (4), close (3), less than close (2), and distant (1). Second item was measured as daily (4), weekly (3), monthly (2), and less often (1). The mean of two items was used as scale score. Referee-entrepreneur tie was measured as the mean of the following three questions: "I know that the third-party had a professional relationship with the entrepreneur prior the recommendation"; "I know that the third-party was engaged in informal social activities, e.g., dinners and other social activities, with the entrepreneur prior the recommendation"; "I know that the third-party and entrepreneur were personal friends prior the recommendation" (Cronbach's alpha is 0.73). This variable and other independent variables were measured by 5point Likert scale ranging from strongly disagree (1) to strongly agree (5). I adapted these items 
from Shane \& Cable (2002), although I had to reformulate them for investors rather than entrepreneurs themselves. Trust of referee was measured by the following item: "What extent do you trust the third-party?”. The distribution value was a 5-point Likert scale from do not trust (1) to trust very much (5).

Dependents. Investment selection is a binary variable of one if the venture received an investment, and zero otherwise. Referral was measured by the following question: "How strong was the recommendation of the third-party?”. The distribution value was 5-point Likert-scale from very weak (1) to very strong (5).

Controls: VC firm age is measured in years. VC firm size is the number of employees. IT industry is a binary variable of one if the firm is in the IT industry and zero otherwise. State ownership is a binary variable of one if the state is a shareholder and zero otherwise. Venture capitalist experience is measured in years. Initial investment sought is measured in \$. Prerevenue is a binary variable of one if the firm had no revenues and zero otherwise.

Entrepreneurial team scale was comprised of two questions: "At least one member of the venture team had previous startup experience"; "At least one member of the venture team had experience in the relevant industry" (Cronbach's alpha is 0.76). Technology/product scale was measured by two items: "The technology employed or products offered by the venture would provide a significant competitive advantage"; "The venture's technology had a strong proprietary position" (Cronbach's alpha is 0.79 ). Growth potential scale was composed of two items: "The venture is a potentially high-growth firm”; "The venture's competitive strategy is superior than its competitors" (Cronbach alpha's is 0.81). These items were adapted from Shane \& Cable (2002).

Construct Validity. Measurements for referee-venture capitalist tie are externally valid, because these items have been proved as valid and reliable in previous research (Burt 2000; Marsden 1990). Measurements for referee-entrepreneur tie, entrepreneurial team, technology/product, and growth potential are externally valid, because previous research has shown that these items are valid and reliable (Shane \& Cable 2002).

Reliability coefficients (Cronbach's alpha) for these measurements were above 0.73. I conducted a confirmatory factor analysis of the measurement model associated with Likert-scale items to assess how well our interview questions load onto the constructs. I found that the comparative fit index is 0.81 , the incremental fit index is 0.89 , and the root mean-squared error 
of approximation is 0.079. In addition, I carried out a factor analysis that focused only on independent variables: Fit indexes were above 0.81 and the factor loading was acceptable (the average on-factor loading was 0.61 ). The findings suggest that our data are valid internally. Shane \& Cable (2002) did the same analysis for same-question items and found even better results.

In order to check for the common-methods variance bias and the social desirability bias, we conducted data cross-validation phone calls. During the interviews, we asked for phone numbers of one referee and one entrepreneur. In all, we obtained phone numbers of twelve Chinese referees, eight Russian referees, nine Chinese entrepreneurs, and five Russian entrepreneurs. We made phone calls to both referees and entrepreneurs.

In the case of referees, we asked several questions to verify perceptions of the venture capitalist. We asked the question: "How close are you with the venture capitalist?”. The answers of twelve Chinese referees and six Russian referees were consistent with our findings. We proposed the statement "I was engaged in informal social activities, e.g., dinners and other social activities, with the entrepreneur prior the recommendation". The answers of nine Chinese referees and eight Russian referees matched our data. We asked the question: "What extent do you trust venture capitalists?”. We found that scales of eleven Chinese referees and seven Russian referees were congruent with the data that we collected from venture capitalists. Finally, we asked the question: "How strong was your recommendation?". The answers of ten Chinese third-parties, and five Russian third-parties were consistent with our data.

In the case of entrepreneurs, we validated several measurements. We asked the question: "I was engaged in informal social activities, e.g., dinners and other social activities, with the third-party prior the recommendation". The answers of eight Chinese entrepreneurs, and four Russian entrepreneurs matched up our findings. We proposed the following statement: "At least one member of the venture team had previous startup experience”. The answers of all Chinese and Russian entrepreneurs were consistent with our data. We come up with the following statement: "The technology employed or products offered by the venture would provide a significant competitive advantage”. Six Chinese entrepreneurs, and three Russian entrepreneurs confirmed our findings. We also verified the answers to the following item: "The venture is a potentially high-growth firm”. Only four Chinese and three Russian entrepreneurs' answers were consistent with venture capitalists' assessment of their ventures. As a whole, these findings 
suggest that our data on venture capitalists' perceptions are valid, reliable, and less biased. To my knowledge, this study is the only study that cross-validated perceptions of triad members, i.e., venture capitalist, referee, and entrepreneur. Two trained research assistants, who were not members of the interview teams, conducted validation interviews in Beijing and Moscow. This study is a cross-level study in terms of unit of analysis. Predictor variables are measured at individual level but investment decision is measured at organizational level. Such research strategies are acceptable as long as measurements and constructs are valid internally and externally (Rousseau 1985).

\section{RESULTS}

\section{Descriptive Statistics}

Table 1 reports the means, standard deviations, and Pearson's correlations for all variables. Table 1 reveals that the mean VC firm age is 4 years (S.D.=2.47), and the mean number of employees (firm size) is 20 (S.D.=13.5). Fourteen percent of private equity firms were fully or partially state-owned. About a half of investee firms were IT firms. The Chinese and Russian venture capitalists appeared to be experienced - the mean year was 5.12 years (S.D.=2.57). The initial investment sought is high by developing country standards (the mean is $\$ 1.199$ thousand), although standard deviation is greater than the mean (S.D.=\$2.112). As was expected, one-third of firms were in pre-revenue stage (S.D=.47).

Table 2 reports the means, standard deviations, and the ANOVA results of the Chinese and the Russian samples. It shows that two samples significantly differ from each other in several variables. Third-party referrals are stronger in Russia. However, referee-venture capitalist tie is stronger in China. The Chinese fund managers have greater trust in referees than the Russians. The Chinese venture capitalists assess entrepreneurial team and technology/product higher than the Russians. Private equity firms based in Moscow are older than firms based in Beijing. Most Chinese entrepreneurial firms were in the IT industry. The initial investment sought by the Russian startups are much smaller than the Chinese ventures.

Insert Table 1 and Table 2 about here

\section{Referral and Investment Decision}

In Table 3, I present the results of the linear regression analysis predicting referral. Model 1 is the base model that examines the main effects of all control variables on referral. The model reveals that entrepreneurial team has significant positive effects on referral, and China dummy 
has significant negative effects on referral. The model is significant ( $F=4.63)$. Model 2 indicates that referee-venture capitalist tie has significant positive effects on referral. The model is significant ( $\mathrm{F}=6.49)$. Hypothesis 1 on referee-venture capitalist tie is supported. Model 3 reveals that referee-entrepreneur tie has significant positive effects on referral. The model is significant ( $\mathrm{F}=5.46)$. Hypothesis 2 on referee-entrepreneur tie is confirmed. Model 4 is the full model. The model reveals that effects of dyadic ties on referral are significant and stable. The model is significant $(\mathrm{F}=6.7)$.

Insert Table 3 about here

In Table 4, I present the results of logistical regression analysis predicting investment decision. Model 1 is the base model. It shows that VC firm size, IT industry, state ownership, entrepreneurial team, and growth potential has significant and positive effects on investment decisions. The impact of firm age, and China dummy is significant and negative. Model 2 reveals that trust of referee has significant positive effects on investment decisions of venture capitalists. Hypothesis 3 on trust of referee is supported.

Insert Table 4 about here

\section{China versus Russia}

Table 5 illustrates the results of linear regression analysis predicting referral in China and Russia. Model 1 and Model 4 are the base models that examine effects of controls on the outcome variable in two countries, and they are significant ( $F=3.47 ; F=4.98)$. Model 2 and Model 5 show the effects of referee-venture capitalist tie on referral in China and Russia. The models reveal that effects of the predictor variable on the outcome variables are significant and positive, and regression coefficients are the same in two countries. Both models are significant $(\mathrm{F}=3.84 ; \mathrm{F}=5.18)$. Hypothesis 4 that predicted greater effects of referee-venture capitalist tie on referral in China has not been confirmed. Models 3 and 6 demonstrate the impact of refereeentrepreneur tie on referral in two cities. They reveal that effects of referee-entrepreneur tie are statistically not significant both in Beijing and Moscow. The models are significant ( $F=3.11$; $\mathrm{F}=4.64)$. Hypothesis 5 that suggested greater effects of Chinese referee-entrepreneur ties on referral is rejected.

Insert Table 5 about here

In Table 6, I present the results of the logistic regression analysis predicting investment decision in two countries. Model 1 reveals that trust of referee has no impact on investment 
decisions in China. In contrast, model 2 shows that trust of referee has significant positive effects on investment decisions of the Russian venture capitalists. Hypothesis 6 that expected a greater impact of trust on investment decision in the Chinese context is not supported.

Insert Table 6 about here

\section{DISCUSSION}

The findings indicate that entrepreneur-referee-venture capitalist (E-R-VC) triad is transitive for the whole sample. Close dyadic ties and interpersonal trust within the triad make the Chinese and Russian triads complete and consistent. This finding is supportive of Granovetter's (1973) theorizing that transitivity of triads is contingent upon tie strength and trust among triple actors. To my knowledge, this is first empirical finding that verifies the role of strong dyadic ties in triad integration and cohesiveness.

Friendly relationships between triad members positively influence referral and investment decision as indicators of transitivity. Strong referee-venture capitalist ties lead to serious referral, because third-parties search for and recommend high quality projects, match investors' policy, involvement, and personality. Matching as a referral mechanism is effective in the venture finance context (Fernandez et al, 2000). Since referees reduce search and identification costs of fund managers, they are inclined to produce enthusiastic recommendations. This makes E-R-VC triads transitive. Because investors are their friends, third-parties seem to encounter fewer social constraints to reach out and convince venture capitalists. A social calculation may also be at work: Strong referrals increase perceived indebtedness of venture capitalists to third-parties, and therefore, referees are motivated to issue good recommendations. Friends are likely to overestimate each other's capabilities and resources, and this overestimation is conducive to solid referrals. Lastly, emotional idiosyncrasies between friends play positive role in producing serious references.

The mechanisms through which referee-entrepreneur relationship influences referral practices are effective. Actors attempt to balance relationships, and reduce social uncertainties. Referral is a chance to establish a balance in their immediate social circles. Information exchange between third-parties and entrepreneurs facilitates effective communication and understanding, and this leads to convincing referrals. Social expectations and informal control devices positively affect referee's assessment of teams' abilities and venture potential. Skillful 
manufacturing of social "receivables" is conducive to triad closure. The matching mechanism is likely to lead to credible references. These factors generate more cohesive triads.

Interpersonal trust between third-parties and investors have positive impacts on investment decision. Trust makes a difference because venture capitalists value opinions of referees on entrepreneurial team ability, technology, and growth potential of the venture. Therefore, the Chinese and Russian fund managers invest in those ventures that have references from trustworthy actors. The entrepreneurs who were recommended by trusted referees are perceived to be less opportunistic, and that they do not engage in dubious activities such as machinations in investment flows, revenues, and cash flows. This makes their ventures worthy to invest, and increases expected returns upon investment. High-trust relationships may bias exchange partners in each other's capabilities and resources, and these biases positively influence investment decisions. Lastly, an outcome of trusted relationships is overconfidence of exchange partners in each other's behavioral predictability, and honesty. In the Chinese and Russian contexts, interpersonal trust between investor and third-party is conducive to positively investment decisions that make small groups such as triple of actors more integrated and cohesive.

Comparative hypotheses on China versus Russia were not confirmed. It appears that referee-venture capitalist tie affects referrals to the same extent in the two countries. The mechanisms through which third-party-investor relationship influences references are effective in the two cities. Thus, transitivity of triads in China and Russia is contingent upon dyadic tie strength. The finding suggests that the industry context (private equity industry) may influence effects of dyadic ties on references to a greater degree. In contrast, the institutional, social, and cultural differences between the two nations have minimal impacts on effects of tie strength on the outcome variable.

While trust of referee has no effects on investors' decisions in China, trust between thirdparty and venture capitalist is conducive to positive decisions in Russia. This finding is the opposite of my prediction. Several explanations are suggested. First, in the society where generalized trust is very low, interpersonal trust plays a greater role, because actors attempt to reduce their risks and uncertainties by trusting concrete individuals rather than relying on abstract rules, norms and values. Second, when public institutions are dysfunctional or nonexistent, particularistic ties are often the only channel of getting things done (Xin and Pearce 
1996). In this way, players are "forced” to rely on personal relationships, and trust individuals to survive. Finally, the Russian cultural heritage, and the Soviet legacy of trusting of individuals and rulers, and distrusting of institutions and rules, may explain why interpersonal trust is important in Russia. However, these explanations are only suggestions, because I do not test directly effects of these factors on interpersonal trust and investment decisions. Thus, in the context of extreme institutional chaos and generalized low trust, trust between two actors in triads makes those triads more transitive. In other words, the way in which interpersonal trust facilitates transitivity is dependent upon the institutional context and generalized trust in that society. The lower the generalized trust, the greater the reliance on individuals rather than on institutions, rules, and norms.

\section{CONCLUSION}

This study examined effects of dyadic ties and interpersonal trust on referrals and investment decisions of venture capitalists as indicators of transitivity of triads. The study found an empirical proof of the hitherto untested postulate of social network theory that transitivity is a function of tie strength and interpersonal trust (Granovetter 1973). Whether triads are transitive depends on referee-investor relationship, referee-entrepreneur tie, and trust of third-party.

Effects of dyadic ties and interpersonal trust on referral and investment decision seems to be universal rather than country or context specific, because industry factors have dominant effects on these outcome variables. Contrary to my expectations, interpersonal trust have greater effects in Russia.

I see a number of contributions of this article to the management research literature. First, this article provides the empirical evidence that network transitivity is contingent upon tie strength and trust. This is an empirical contribution to the research literature on networks. Second, to my knowledge, this is first study of venture capital practices by employing the concept of transitivity, and therefore, I claim a contribution to the entrepreneurship literature. Third, to my knowledge, this is study is first and only comparative study of the Chinese and Russian private equity industries. Therefore, this article makes a contribution to the growing management literature on transition economies.

Several limitations should be discussed. This is a retrospective study about past investment decisions, and therefore, the extent to which respondents recall information accurately might be an issue. The sample size is small, and sampling is neither complete nor 
random. There is also an issue of the potential nonindependence of observations. I used social capital measurements that were developed in the Western context for measuring indigenous phenomena deeply rooted the Chinese and Russian cultures - guanxi and svyazi. In this way, I may have overlooked unique features of Chinese guanxi and Russian svyazi. The private equity industries in China and Russia are young. This institutional condition may have affected our results, although I assume that all the respondents have been exposed to the same conditions to the same extent.

An important research implication is that one should test the postulate of transitivity in other industry contexts and other country contexts. A practical implication is that entrepreneurs and venture capitalists are suggested to nurture dyadic ties and trust in triads to increase benefits generated from networks. 


\section{REFERRENCES}

Batjargal, B. and M. Liu. 2004. Entrepreneurs' access to private equity in China: The role of social capital. Organization Science 15 (2): 159-172.

Bian, Y. 1997. Bringing strong ties back in: Indirect ties, network bridges, and job searches in China. American Sociological Review, 62: 366-385.

Bruton G., D. Ahlstrom. 2003. An institutional view of China's venture capital industry. Journal Business Venturing 18 (2): 233-259.

Burt, R. 1999. Entrepreneurs, distrust and third parties. In L. Thompson, J. Levine, D. Messick, (Eds.) Shared Cognition in Organizations: The Management of Knowledge, New Jersey: Lawrence Erlbaum Associates.

Burt, R. 2000. Decay Functions, Social Networks 22: 1-28.

BusinessWeek. 2004. March 22, New York.

Business Weekly. 2003. February 18-24, Beijing.

Cable, D. \& Shane, S. 1997. A prisoner's dilemma approach to entrepreneur-venture capitalist relationship. Academy of Management Review, 22(1): 142-176.

Dai, J. 2002. Newly born private enterprise owners in China, Social Sciences in China, 23: 124134.

Davis, J. 1970. Clustering and hierarchy in interpersonal relations: Testing two graph theoretical models on 742 sociomatrices. American Sociological Review, 35 (5): 843-851.

Eisenhardt, K. \& Tabrizi, B. 1995. Accelerating adaptive processes: Product innovation in the global computer industry. Administrative Science Quarterly, 40 (1): 84-110.

E-Trust Investment Group. 2004. www.e-trust.com

Farh, L. Tsui, A. Xin, K., B. Cheng, 1998 The influence of relational demography and guanxi: The Chinese case. Organization Science. 9: 471-488.

Fernandez, R. E. Castilla, 2001. How much is that network worth? Social capital returns for referring prospective hires. N. Lin, K. Cook, R. Burt, (Eds.) Social Capital: Theory and Research, Aldine De Gruyter, New York, 85-104.

Fernandez, R. E. Castilla, P. Moore 2000 Social capital at work: Networks and employment at a phone center. American Journal of Sociology, 105: 1288-1356.

Granovetter, M. S. 1973. The strength of weak ties. American Journal of Sociology, 78, 13601380 . 
Guseva, A. \& A. Rona-Tas, 2001 Uncertainty, risk and trust: Russian and American credit card markets compared. American Sociological Review, 66: 623-46.

Kharkhordin, O. \& T. Gerber, 1994 Russian directors' business ethic: A study of industrial enterprises in St. Petersburg, 1993. Europe-Asia Studies, 46: 1075-1107.

King, G. \& L. Zeng. 2001. Logistic regression in rare events data. Political Analysis, 9: 137-163.

Krackhardt, D. \& M. Kilduff, 1999. Whether close or far: Social distance effects on perceived balance in friendship networks. Journal of Personality and Social Psychology, 76 (5): 770-782.

Hallinan, M. \& E. Hutchins. Structural effects on dyadic change. Social Forces, 59 (1): 225-245.

Heider, F. 1964. The psychology of interpersonal relations, London: John Wiley \& Sons.

Hellman J. M. Puri, 2000. The interaction between product market and financing strategy: The role of venture capital. Review of Financial Studies, 13: 959-984.

Hitt, M., D. Ahlstrom, T. Dacin, E. Levitas, L. Svobodina, 2004 The institutional effects on strategic alliance partner selection in transition economies: China versus Russia. Organization Science, 15 (2): 173-185.

Holland, P. \& S. Leinhardt. 1976. Local structure in social networks. Sociological Methodology, 7: 1-45.

Ledeneva, A. 1998 Russia's economy of favours: Blat, networking and informal exchange, Cambridge: Cambridge University Press.

Lerner, J. 1995. Venture capitalists and the oversight of private firms. Journal of Finance, 1: 301-318.

Lin, N. 2001. Guanxi: A conceptual analysis. In A. So, N. Lin, and D. Poston (Eds), The Chinese Triangle of Mainland China, Taiwan, and Hong Kong, Comparative Institutional Analysis, London: Greenwood Press, 153-166.

Liu, M. 2001. Venture Capital: Attractive Opportunities in China, Beijing: China Business, in Chinese.

Louch, H. 2000. Personal network integration: Transitivity and homophily in strong-tie relations. Social Networks, 22: 45-64.

Marsden, P. 1990. Network data and measurement. Annual Review of Sociology, 16: 435-463.

McCullagh, P. \& J. A. Nelder, 1999. Generalized Linear Models. Second edition, New York: Chapman \& Hall. 
McPherson, M. L. Smith-Lovin, and J. Cook, 2001. Birds of a feather: Homophily in social networks. Annual Review of Sociology, 27: 415-444.

Newman, M. 2001.Structure of scientific collaboration networks. Proceed. Nation. Academy Sci. USA, 98: 404-409.

Park, S., Y. Luo, 2001 Guanxi and organizational dynamics: Organizational networking in Chinese firms, Strategic Management J. 22: 455-477.

Petrovskii, A.1991 Trekhfaktornaya model ‘znachimogo drugogo’. Voprosy Psikhologii, 1:7-18.

Raiser, M. C. Haerpfer, T. Nowotny, \& C. Wallace. 2001. Social capital in transition: A first look at the evidence. Working paper, \# 62, European Bank of Reconstruction and Development, London.

Ralston, D. D. Holt, R. Terpstra, Y. Kai-cheng, 1997. The Impact of national culture and economic ideology on managerial work values: A study of the United States, Russia, Japan and China. Journal of International Business Studies, 28 (1): 177-207.

Robinson, D. Balkwell, J. 1995. Density, transitivity, and diffuse status in task-oriented groups. Soc. Psych. Quart. 58: 241-254.

Rousseau, D. 1985. Issues of Level in Organizational Research: Multi-level and Cross-Level Perspectives, Research in Organizational Behavior, 7: 1-37.

Sapienza, H \& Korsgaard, M. 1996. The role of procedural justice in entrepreneur-venture capital relations. Academy of Management Journal, 39: 544-574

Sedaitis, J. 1998 The alliances of spin-offs versus start-ups: Social ties in the genesis of postSoviet alliances. Organ. Sci. 9: 368-381.

Shane, S. \& Cable, D. 2002. Network ties, reputation and the financing of new ventures. Management Science, 48 (3): 364-381.

Shane S. \& T. Stuart. 2002. Organizational endowments and the performance of university startups. Management Science, 48 (1): 154-170.

Sorenson, O. \& Stuart, T. 2001. Syndication networks and the spatial distribution of venture capital investments. American Journal of Sociology, 106 (6): 1546-88.

Sheng, J. B. Li, J. Miao. 2003. Investment in China, Opportunities in private equity and venture capital, Beijing: Tsinghua University Press.

TACIS. 2001. Venture capital in Russia, policy paper. Belguim: Brussels. 
Tsui, A, L. Farh., K. Xin, 2000 Guanxi in the Chinese context.” In J.T. Li, A. Tsui and E. Weldon, (eds.), Management and organization in the Chinese context, 225-244.London: Macmillan.

Uzzi, B. \& J. Gillespie, 2002. Knowledge spillover in corporate financing networks: Embeddedness and the firm’s debt performance. Strategic Management J. 23: 595-618.

Xin, K. J. Pearce. 1996. Guanxi: Connections as substitutes for formal institutional support. Acad. Management J. 39 1641-1658.

Yang, M. 1994 Gifts, favors and banquets: The art of social relationships in China, Ithaca, NY: Cornell University Press.

Zacharakis, A., Shepherd, D. 2001. The nature of information and overconfidence on venture capitalists’ decision making. Journal of Business Venturing, 16: 311-332. 
Figure 1: Triad of Entrepreneur, Referee (Third Party), and Venture Capitalist

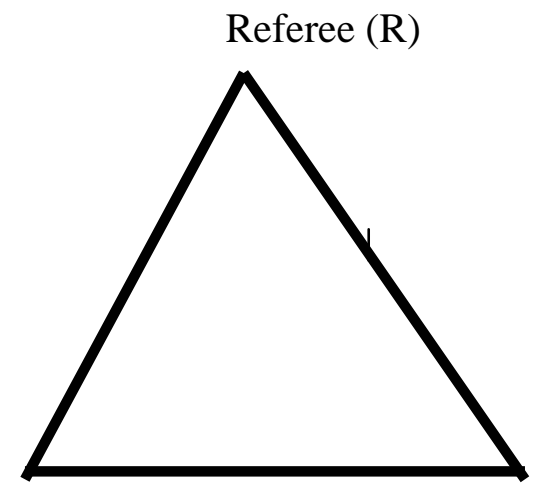

Entrepreneur (E)

Venture Capitalist (VC) 
Table 1. Descriptive Statistics and Pearson's Correlations

\begin{tabular}{|c|c|c|c|c|c|c|c|c|c|c|}
\hline & Variables & $\mathbf{N}$ & M & SD & 1 & 2 & 3 & 4 & 5 & 6 \\
\hline 1 & Investment decision & 122 & .50 & .50 & & & & & & \\
\hline 2 & Referral & 120 & 3.49 & 1.1 & .17 & & & & & \\
\hline 3 & $\begin{array}{l}\text { Referee-venture } \\
\text { capitalist tie }\end{array}$ & 121 & 2.42 & .66 & $.28 * *$ & .14 & & & & \\
\hline 4 & $\begin{array}{l}\text { Referee-entrepreneur } \\
\text { tie }\end{array}$ & 121 & 2.89 & .73 & $.2^{*}$ & $.34 * *$ & $.29 * *$ & & & \\
\hline 5 & Trust of referee & 121 & 2.99 & .95 & $.28 * *$ & .12 & $.38 * *$ & .1 & & \\
\hline 6 & Entrepreneurial team & 121 & 3.90 & .89 & $.32 * *$ & .01 & $.24 * *$ & .11 & $.4 * *$ & \\
\hline 7 & Technology/product & 121 & 3.6 & .91 & $.54 * *$ & $.22^{*}$ & $.22 *$ & $.32 * *$ & $.22 *$ & $.43^{* *}$ \\
\hline 8 & Growth potential & 121 & 3.77 & .99 & $.64^{* *}$ & $.24 * *$ & $.24 * *$ & $.39 * *$ & .09 & $.28 * *$ \\
\hline 9 & Firm age & 124 & 4 & 2.47 & .06 & $.26 * *$ & $.26 * *$ & .15 & -.09 & $-.28 *$ \\
\hline 10 & Firm size & 124 & 20 & 13.5 & -.01 & .05 & .05 & .02 & .13 & -.05 \\
\hline 11 & IT industry & 124 & .48 & .5 & .16 & -.07 & $.21 *$ & .03 & $.21 *$ & $.2 *$ \\
\hline 12 & State ownership & 124 & .14 & .35 & .07 & -.00 & -.04 & .03 & $.2 *$ & $.2 *$ \\
\hline 13 & $\begin{array}{l}\text { Venture capitalist } \\
\text { experience }\end{array}$ & 124 & 5.12 & 2.57 & .06 & .13 & .08 & .12 & -.01 & -.01 \\
\hline 14 & $\begin{array}{l}\text { Initial investment } \\
\text { (Thousand \$) }\end{array}$ & 111 & 1199 & 2112 & -.08 & -.11 & -.03 & -.12 & .15 & .15 \\
\hline 15 & Pre-revenue & 121 & .33 & .47 & $\begin{array}{c}- \\
.25^{* *}\end{array}$ & -.02 & $.24 * *$ & $-.18^{*}$ & $-.21 *$ & $-.21 *$ \\
\hline 16 & China & 124 & .51 & 50 & 0 & ${ }^{-} .43^{* *}$ & $.33 * *$ & -.07 & $.28 * *$ & $.28^{* *}$ \\
\hline
\end{tabular}

Table 1. Descriptive Statistics and Pearson's Correlations (Con't)

\begin{tabular}{llccccccccc}
\hline & \multicolumn{1}{c}{ Variables } & $\mathbf{7}$ & $\mathbf{8}$ & $\mathbf{9}$ & $\mathbf{1 0}$ & $\mathbf{1 1}$ & $\mathbf{1 2}$ & $\mathbf{1 3}$ & $\mathbf{1 4}$ & $\mathbf{1 5}$ \\
\hline 8 & Growth potential & $.7^{* *}$ & & & & & & & & \\
9 & Firm age & -.14 & .01 & & & & & & \\
10 & Firm size & - & .01 & $.52^{* *}$ & & & & & \\
& & $.25^{* *}$ & & & & & & & \\
11 & IT Industry & .02 & .08 & -.16 & -.08 & & & & \\
12 & State ownership & .05 & .05 & $.36^{* *}$ & -.09 & .05 & & & \\
13 & Venture capitalist & .01 & $.21^{*}$ & $.54^{* *}$ & $.44^{* *}$ & -.08 & $.36^{* *}$ & & \\
& $\begin{array}{l}\text { experience } \\
14\end{array}$ & $\begin{array}{l}\text { Initial investment } \\
\text { (Thousand \$) }\end{array}$ & $.23^{*}$ & - & .08 & -.02 & -.09 & -.03 & -.13 & \\
15 & & $.25^{* *}$ & & & & & & \\
& Pre-revenue & - & $-.18^{*}$ & .08 & -.09 & -.17 & .02 & .14 & .11 & \\
16 & China & $.28^{* *}$ & & & & & & & & \\
& & $.28^{* *}$ & .02 & - & -.07 & $.25^{* *}$ & .03 & -.1 & $.29 * *$ & -.14 \\
\hline
\end{tabular}

${ }^{*} \mathrm{p}<0.05$

** $\mathrm{p}<0.01$ 
Table 2. Descriptive Statistics and ANOVA of the Chinese and Russian Samples

\begin{tabular}{|c|c|c|c|c|c|c|c|c|}
\hline & & \multicolumn{3}{|c|}{ China } & \multicolumn{3}{|c|}{ Russia } & \multirow{2}{*}{$\begin{array}{c}\text { ANOVA } \\
\text { model }\end{array}$} \\
\hline & & $\mathrm{N}$ & Means & S.D. & $\mathrm{N}$ & Means & S.D. & \\
\hline 1 & Referral & 60 & 3 & 1.18 & 60 & 3.96 & .75 & $27.32 * * *$ \\
\hline 2 & $\begin{array}{l}\text { Referee-venture capitalist } \\
\text { tie }\end{array}$ & 61 & 2.63 & .63 & 60 & 2.2 & .62 & $14.57 * * *$ \\
\hline 3 & Referee-entrepreneur tie & 61 & 2.84 & .94 & 60 & 2.95 & .44 & .59 \\
\hline 4 & Trust of referee & 61 & 3.26 & 1.11 & 60 & 2.71 & .66 & $10.71 * * *$ \\
\hline 5 & Entrepreneurial team & 61 & 4.41 & .85 & 60 & 3.39 & .6 & $57.14 * * *$ \\
\hline 6 & Technology/product & 61 & 3.77 & 1.05 & 60 & 3.43 & .69 & $4.51^{*}$ \\
\hline 7 & Growth potential & 61 & 3.79 & 1.18 & 60 & 3.75 & .75 & .06 \\
\hline 8 & Firm age & 64 & 3.12 & 1.06 & 60 & 5 & 3.12 & $20.52 * * *$ \\
\hline 9 & Firm size & 64 & 19 & 9 & 60 & 20 & 16 & .6 \\
\hline 10 & IT industry & 64 & .6 & .49 & 60 & .35 & .48 & $8.8^{* *}$ \\
\hline 11 & State ownership & 64 & .15 & .36 & 60 & .13 & .34 & .12 \\
\hline 12 & $\begin{array}{l}\text { Venture capitalist } \\
\text { experience }\end{array}$ & 64 & 4.86 & 2.61 & 60 & 5.4 & 2.51 & 1.33 \\
\hline 13 & $\begin{array}{l}\text { Initial investment } \\
\text { (Thousand \$) }\end{array}$ & 55 & 1835 & 2830 & 56 & 575 & 513 & $10.7 * * *$ \\
\hline 14 & Pre-revenue & 61 & .26 & .44 & 60 & .4 & .49 & 2.6 \\
\hline
\end{tabular}

$* \mathrm{p}<0.05$

$* * \mathrm{p}<0.01$

$* * * \mathrm{p}<0.001$ 
Table 3. Linear Regression Analysis Predicting Referral (N=124)

\begin{tabular}{|c|c|c|c|c|}
\hline & Model 1 & Model 2 & Model 3 & Model 4 \\
\hline \multicolumn{5}{|l|}{ Controls } \\
\hline Firm age & .2 & .279 & .09 & .18 \\
\hline Firm size & -.05 & $-.31^{*}$ & -.01 & -.23 \\
\hline IT industry & .05 & -.01 & .04 & -.01 \\
\hline State ownership & -.11 & -.16 & -.08 & -.13 \\
\hline Venture capitalist experience & .05 & .12 & .05 & .11 \\
\hline Initial investment (Thousand \$) & .01 & .01 & .03 & .03 \\
\hline Pre-revenue & -.06 & -.04 & -.03 & -.03 \\
\hline Entrepreneurial team & .229 & $.27^{*}$ & .219 & $.25 *$ \\
\hline Technology/product & .2 & .04 & .14 & .03 \\
\hline Growth potential & .1 & .07 & .05 & .04 \\
\hline China & $-.51 * * *$ & $-.59 * * *$ & $-.51 * * *$ & $-.58 * * *$ \\
\hline \multicolumn{5}{|l|}{ Predictors } \\
\hline Referee-venture capitalist tie & & $.41^{* * *}$ & & $.33^{* * *}$ \\
\hline Referee-entrepreneur tie & & & $.29 * * *$ & $.2 *$ \\
\hline Model F & $4.63^{* * *}$ & $6.49 * * *$ & $5.64 * * *$ & $6.7^{* * *}$ \\
\hline Adjusted R square & .26 & .37 & .33 & .4 \\
\hline \multicolumn{5}{|c|}{ Values represent standardized B coefficients. } \\
\hline $\begin{array}{l}\text { Ip }<0.1 \\
* \mathrm{p}<0.05 \\
* * \mathrm{p}<0.01 \\
* * * \mathrm{p}<0.001\end{array}$ & & & & \\
\hline
\end{tabular}


Table 4. Logistic Regression Analysis Predicting Investment Decision (N=124)

\begin{tabular}{|c|c|c|}
\hline & Model 1 & Model 2 \\
\hline Controls & B & B \\
\hline Firm age & $-.61^{*}$ & $-.42 \rrbracket$ \\
\hline Firm size & $.06 \rrbracket$ & .01 \\
\hline IT industry & 1.129 & .85 \\
\hline State ownership & $4^{* *}$ & 2.31 \\
\hline Venture capitalist experience & .04 & .19 \\
\hline Initial investment (Thousand \$) & .01 & .01 \\
\hline Pre-revenue & -.58 & -.92 \\
\hline Entrepreneurial team & $1.39 *$ & $1.25^{*}$ \\
\hline Technology/product & .7 & .41 \\
\hline Growth potential & $2.17 * * *$ & $2.44 * * *$ \\
\hline China & $-3.99 * *$ & $-3.93 * *$ \\
\hline \multicolumn{3}{|l|}{ Predictor } \\
\hline Trust of referee & & $.95^{*}$ \\
\hline$-2 L L$ & 77.16 & 73.36 \\
\hline Chi-square & $76.63 * * *$ & $80.43^{* * *}$ \\
\hline
\end{tabular}

Values represent B coefficients.

$9 \mathrm{p}<0.1$

${ }^{*} \mathrm{p}<0.05$

$* * \mathrm{p}<0.01$

$* * * \mathrm{p}<0.001$ 
Table 5. Linear Regression Analysis Predicting Referral in China and Russia

\begin{tabular}{|c|c|c|c|c|c|c|}
\hline & \multicolumn{3}{|c|}{ China } & \multicolumn{3}{|c|}{ Russia } \\
\hline & Model 1 & Model 2 & Model 3 & Model 4 & Model 5 & Model 6 \\
\hline \multicolumn{7}{|l|}{ Controls } \\
\hline Firm age & $.71 * * *$ & $.66^{* * *}$ & $.65^{* *}$ & -.48 & -.58 & -.46 \\
\hline Firm size & .14 & -.02 & .13 & -.06 & -.19 & -.08 \\
\hline IT industry & .05 & .01 & .05 & .05 & .04 & .02 \\
\hline State ownership & -.06 & -.1 & -.06 & -.09 & .02 & -.06 \\
\hline $\begin{array}{l}\text { Venture capitalist } \\
\text { experience }\end{array}$ & $.31 *$ & $.34 *$ & .299 & .719 & $.77^{*}$ & .669 \\
\hline $\begin{array}{l}\text { Initial investment } \\
\text { (Thousand \$) }\end{array}$ & -.309 & -.24 & -.27 & .08 & -.01 & .1 \\
\hline Pre-revenue & -.05 & -.02 & -.04 & .11 & .03 & .14 \\
\hline Entrepreneurial team & $.24 \rrbracket$ & $.31^{*}$ & .239 & $.38 *$ & $.34 *$ & $.48 *$ \\
\hline Technology/product & .09 & -.05 & .09 & .21 & .04 & .18 \\
\hline Growth potential & .15 & -.09 & -.15 & $.33 *$ & $.24 \rrbracket$ & $.41 *$ \\
\hline \multicolumn{7}{|l|}{ Predictors } \\
\hline $\begin{array}{l}\text { Referee-venture capitalist } \\
\text { tie }\end{array}$ & & $.3 *$ & & & $.3 *$ & \\
\hline Referee-entrepreneur tie & & & .07 & & & -.15 \\
\hline Model F & $3.47 * *$ & $3.84 * * *$ & $3.11 * *$ & $4.98 * * *$ & $5.18 * * *$ & $4.64^{* * *}$ \\
\hline Adjusted R square & .31 & .37 & .3 & .42 & .45 & .42 \\
\hline
\end{tabular}

Values represent standardized B coefficients.

$9 \mathrm{p}<0.1$

$* \mathrm{p}<0.05$

$* * \mathrm{p}<0.01$

$* * * \mathrm{p}<0.001$ 
Table 6. Logistic Regression Analysis Predicting Investment Decision in China and Russia (N=124)

\begin{tabular}{|c|c|c|}
\hline & $\begin{array}{c}\text { China } \\
\text { Model } 1 \\
\end{array}$ & $\begin{array}{c}\text { Russia } \\
\text { Model } 2\end{array}$ \\
\hline \multicolumn{3}{|l|}{ Controls } \\
\hline Firm age & -.1 & .36 \\
\hline Firm size & -.02 & -.14 \\
\hline IT industry & .19 & .37 \\
\hline State ownership & -.46 & -5.06 \\
\hline Venture capitalist experience & .11 & $1.02 \Phi$ \\
\hline Initial investment (Thousand \$) & .00 & $-.01 \rrbracket$ \\
\hline Pre-revenue & -.47 & -1.779 \\
\hline \multicolumn{3}{|l|}{ Predictor } \\
\hline Trust of referee & .49 & $2.78 * *$ \\
\hline$-2 L L$ & 71.07 & 48.05 \\
\hline Chi-square & 5 & $29.58^{* * *}$ \\
\hline
\end{tabular}

Values represent B coefficients.

$9 \mathrm{p}<0.1$

$* \mathrm{p}<0.05$

$* * \mathrm{p}<0.01$

$* * * \mathrm{p}<0.001$ 


\section{DAVIDSON INSTITUTE WORKING PAPER SERIES - Most Recent Papers}

The entire Working Paper Series may be downloaded free of charge at: www.wdi.bus.umich.edu

CURRENT AS OF 2/15/05

\begin{tabular}{|c|c|c|}
\hline Publication & Authors & Date \\
\hline $\begin{array}{l}\text { No. 753: Internet Entrepreneurship: Networks and Performance of } \\
\text { Internet Ventures In China }\end{array}$ & Bat Batjargal & Feb. 2005 \\
\hline $\begin{array}{l}\text { No. 752: Network Triads: Transitivity, Referral and Venture Capital } \\
\text { Decisions in China and Russia }\end{array}$ & Bat Batjargal & Feb. 2005 \\
\hline $\begin{array}{l}\text { No. 751: Software Entrepreneurship: Knowledge Networks and } \\
\text { Performance Of Software Ventures In China and Russia }\end{array}$ & Bat Batjargal & Feb. 2005 \\
\hline $\begin{array}{l}\text { No. 750: Retained State Shareholding in Chinese PLCs: Does } \\
\text { Government Ownership Reduce Corporate Value? }\end{array}$ & Lihui Tian and Saul Estrin & Feb. 2005 \\
\hline No. 749: Financial Development and Technology & Solomon Tadesse & Feb. 2005 \\
\hline No. 748: Banking Fragility and Disclosure: International Evidence & Solomon Tadesse & Feb. 2005 \\
\hline $\begin{array}{l}\text { No. 747: Consolidation, Scale Economies and Technological Change in } \\
\text { Japanese Banking }\end{array}$ & Solomon Tadesse & Feb. 2005 \\
\hline $\begin{array}{l}\text { No. 746: Trade Creation and Diversion Effects of Europe’s Regional } \\
\text { Liberalization Agreements }\end{array}$ & Yener Kandogan & Feb. 2005 \\
\hline No. 745: Quality of Institutions, Credit Markets and Bankruptcy & Christa Hainz & Feb. 2005 \\
\hline $\begin{array}{l}\text { No. 744: How Transition Paths Differ: Enterprise Performance in Russia } \\
\text { and China }\end{array}$ & Sumon Bhaumik and Saul Estrin & Jan. 2005 \\
\hline $\begin{array}{l}\text { No. 743: Inflation Targeting, Between Rhetoric and Reality. The Case } \\
\text { of Transition Economies }\end{array}$ & Daniel Daianu and Laurian Lungu & Jan. 2005 \\
\hline $\begin{array}{l}\text { No. 742: How Does Law Affect Finance? An Empirical Examination of } \\
\text { Tunneling in an Emerging Market }\end{array}$ & $\begin{array}{l}\text { Vladimir Atanasov, Conrad S. } \\
\text { Ciccotello, \& Stanley B. Gyoshev }\end{array}$ & Jan. 2005 \\
\hline $\begin{array}{l}\text { No. 741: Do Insider Trading Laws Matter? Some Preliminary } \\
\text { Comparative Evidence }\end{array}$ & Laura Nyantung Beny & Jan. 2005 \\
\hline $\begin{array}{l}\text { No. 740: Autopsy on an Empire: Understanding Mortality in Russia and } \\
\text { the Former Soviet Union }\end{array}$ & $\begin{array}{l}\text { Elizabeth Brainerd and David M. } \\
\text { Cutler }\end{array}$ & Jan. 2005 \\
\hline $\begin{array}{l}\text { No. 739: Not Separate, Not Equal: Poverty and Inequality in Post- } \\
\text { Apartheid South Africa }\end{array}$ & $\begin{array}{l}\text { Johannes G. Hoogeveen and Berk } \\
\text { Özler }\end{array}$ & Jan. 2005 \\
\hline $\begin{array}{l}\text { No. 738: The Marketing Structure in Agribusiness during the Transition } \\
\text { in Bulgaria }\end{array}$ & $\begin{array}{l}\text { Steve Murray, Yordan Staykov, } \\
\text { and Valentin Katzerov }\end{array}$ & Jan. 2005 \\
\hline No. 737: Passive Creditors & $\begin{array}{l}\text { Koen Schoors and Konstantin } \\
\text { Sonin }\end{array}$ & Jan. 2005 \\
\hline $\begin{array}{l}\text { No. 736: From a currency board to the euro: Public attitudes toward } \\
\text { unilateral euroization in Bulgaria }\end{array}$ & Neven T. Valev & Jan. 2005 \\
\hline No. 735: Dictators and Their Viziers: Agency Problems in Dictatorships & $\begin{array}{l}\text { Georgy Egorov and Konstantin } \\
\text { Sonin }\end{array}$ & Jan. 2005 \\
\hline $\begin{array}{l}\text { No. 734: Foreign Investment, Corporate Ownership, and Development: } \\
\text { Are Firms in Emerging Markets Catching Up to the World Standard? }\end{array}$ & $\begin{array}{l}\text { Klara Sabirianova, Jan Svejnar, } \\
\text { and Katherine Terrell }\end{array}$ & Jan. 2005 \\
\hline $\begin{array}{l}\text { No. 733: Businessman Candidates: Special-Interest Politics in Weakly } \\
\text { Institutionalized Environments }\end{array}$ & $\begin{array}{l}\text { Scott Gehlbach and Konstantin } \\
\text { Sonin }\end{array}$ & Dec. 2004 \\
\hline $\begin{array}{l}\text { No. 732: Measuring the Institutional Change of the Monetary Regime } \\
\text { in a Political Economy Perspective }\end{array}$ & $\begin{array}{l}\text { Nikolay Nenovsky and Yorgos } \\
\text { Rizopoulos }\end{array}$ & Dec. 2004 \\
\hline $\begin{array}{l}\text { No. 731: Impact of Regulated Price Adjustments on Price Variability in } \\
\text { a Very Low Inflation Transition Economy: Case of Armenia }\end{array}$ & Aghassi Mkrtchyan & Nov. 2004 \\
\hline $\begin{array}{l}\text { No. 730: Reform, FDI and Economic Growth: Tale of the Tortoise and } \\
\text { the Hare }\end{array}$ & $\begin{array}{l}\text { Bruno Merlevede and Koen } \\
\text { Schoors }\end{array}$ & Nov. 2004 \\
\hline $\begin{array}{l}\text { No. 729: The Effects of Transition and Political Instability On Foreign } \\
\text { Direct Investment Inflows: Central Europe and the Balkans }\end{array}$ & $\begin{array}{l}\text { Josef C. Brada, Ali M. Kutan, } \\
\text { and Taner M. Yigit }\end{array}$ & Nov. 2004 \\
\hline $\begin{array}{l}\text { No. 728: Institutional Distance and International Business Strategies } \\
\text { in Emerging Economies }\end{array}$ & $\begin{array}{l}\text { Delia Ionascu, Klaus E. Meyer, } \\
\text { and Saul Erstin }\end{array}$ & Nov. 2004 \\
\hline No. 727: Explaining Patterns of Corruption in the Russian Regions & $\begin{array}{l}\text { Phyllis Dininio and Robert W. } \\
\text { Orttung }\end{array}$ & Nov. 2004 \\
\hline $\begin{array}{l}\text { No. 726: The Politics of Institutional Learning and Creation: Bank } \\
\text { Crises and Supervision in East Central Europe }\end{array}$ & Gerald A. McDermott & Nov. 2004 \\
\hline
\end{tabular}

